\title{
Reklamlar Aracılığıyla Betimlenen Tüketim Ritüelleri ve Marka Sadakati İlișkisi
}

\author{
Ebru Gökaliler ${ }^{1}$ \\ Ezgi Saatcıŏlu²
}

öz

Ritüeller, geçmişten günümüze değin insan yaşamının bir parçası olmuştur. Tüketim toplumunda markalar, toplumda yer alan ritüellerden yararlanarak veya kendilerine özgü birtakım ritüeller yaratarak tüketiciler ile bağ kurmaktadırlar. Bu süreçte bir anlam taşıyıcısı olarak reklamlar da önemli bir rol üstlenmektedirler. Bu bağlamda markalar, reklamlarda kendilerine özgü tüketim ritüellerini sunmakta ve kendilerini bu tüketim ritüelleri aracılığı ile konumlandırmaktadırlar. Bu çalışmanın amacı, markaların reklamlarında kullandıkları ritüel olgusunun marka sadakatiyle ilişkisini araștırmaktır. Ayrıca araştırma kapsamında tüketicilerin marka ritüellerini hangi koşullarda tüketim alışkanlıklarına dönüştürdükleri de değerlendirilmiştir. Çalışmada nitel araştırma tekniklerinden odak grup görüşme yöntemi uygulanmıştır. Amaçsal örneklem yöntemiyle seçilen katılımcılara marka ritüellerinin tüketicilerin tüketim ritüellerine yansıması ve reklamlar aracılığıyla oluşturulan marka ritüelleri ile ilgili görüşleri sorulmuştur. Araştırma sonuçlarına göre ritüel yaratan markaların tüketici ile bağ kurma sürecinde etkili olduğu saptanmıştır. Katılımcılara göre marka ritüelleri, kültürel değerleri yansıtmaktadır. Ritüellerine reklamlarda yer veren markaların reklamları dikkat çekmektedir. Bir diğer araştırma bulgusu ise marka ritüellerinin dikkat çekmesine karşın katılımcıların bu ritüelleri tüketim ritüellerine yansıtmadıkları saptanmıştır. Ritüel ile marka sadakati arasında olumlu ilişki saptanırken bazı katılımcılar, sadakatin sadece ritüel yaratacağı ancak uzun süreli olamayacağı görüşündedirler.

\section{Relationship Between Consumption Rituals Represented By Ads and Brand Loyalty}

\begin{abstract}
Rituals have always been a part of human life. In today's society brands use existing rituals of the society or create their own rituals in order to establish and sustain a bond between their brand and the consumers. During this process, ads play an important role as they carry the meaning. Within this context, brands represent consumption rituals in their ads and they position themselves through these consumption rituals. This study aims to examine the relationship between these rituals used in ads and
\end{abstract}

1 Yrd. Doç. Dr. Yaşar Üniversitesi, İletişim Fakültesi

2 Doktora Öğrencisi Yaşar Üniversitesi, İletişim ABD 
brand loyalty. This study also evaluated the situations that the consumers transform brand rituals into consumption rituals. In accordance with the purpose of this study, a qualitative research was carried out through focus group interview. As a result, it was determined that the ritual brands were effective during the bonding established between the brand and the consumers. According to the participants, brand rituals reflect cultural values. Although brands that include rituals in their ads get consumers's attention, some of the participants mentioned that they did not take those rituals into account during their consumption process. The result of the study revealed that there was a positive relationship between the rituals and brand loyalty but some of the participants mentioned that loyalty could only create rituals which would not last long.

Keywords: Consumption Rituals, Advertising, Brand Loyalty 


\section{Giriș}

$\mathrm{T}$ üketim toplumunda intiyaç temelli maddi tüketimden çok manevi değerlerin maddileşerek tüketimi söz konusudur. Tüketicilere mesaj iletim sürecinin önemli aracılarından biri olarak reklam, anlam taşıyıcısı olma özelliği ile tüketicilere tüketim ideolojisini aşılamakta ve birtakım kültürel değerlerin inşasında ve iletiminde de önemli bir rol oynamaktadır.

Ritüeller, dini ve toplumsal açıdan önem taşıyan, tekrara dayalı uygulamalardır. Bu bağlamda toplum içerisinde veya belirli gruplar arasında bağ kurma açısından önem teşkil etmektedir. Tüketim toplumunda markalar da bireylerin yaşamlarının bir parçası olan ritüelleri kendi markalarıyla eşleştirerek ya da yeni ritüeller yaratarak tüketicilerle etkileşime geçmektedirler. Bu tüketim ritüellerinin yaratılmasında bir anlam taşıyıcısı olarak reklamlar da önemli bir rol üstlenmektedirler. Bu bağlamda markalar, reklamlarda sunulan tüketim ritüelleriyle konumlandırılmaktadırlar.

Özellikle yabancı literatürde tüketim ritüelleri üzerine 1980'ler itibari ile pek çok çalışma yapıldığı görülebilmektedir. Bununla birlikte Türkiye'de tüketim ritüelleri konusunun çok fazla ele alınmadığı, tüketim ritüelleri ve reklam ilişkisine yönelik çalışmalara bakıldığında ise reklam kültür ilişkisine odaklanıımış çalışmaların bulunduğu (Ün, 1996; Ödül, 2008; Korkmaz, 2008; Yağlıcı, 2009) görülmektedir. Bu çalışmada, tüketicilerin tüketim ve marka ritüellerine bakış açısı, ritüel içeren reklamların farkındalık yaratmadaki etkisinin ve tüketim ritüellerinin marka sadakati yaratım sürecindeki yerinin ortaya konulması amaçlanmaktadır. Çalışmada odak grup yöntemiyle markaların oluşturdukları tüketim ritüellerin reklamlar aracılığıyla aktarımı ve tüketici zihninde marka sadakatine yansıması araştırılmıştır.

\section{Tüketim ve Tüketim Kültürü}

Tüketim insanoğlunun var olduğu dönemden itibaren süregelen bir olgudur. Tüketim denildiğinde akla daha çok maddi bir tüketim gelmekle birlikte günümüzde tüketim, manevi değerlerin maddeleştirilerek tüketilmesini kapsamaktadır (Coşgun, 2012: 844). Tüketim, toplumsal olarak oluşturulmakta ve tarihsel süreç içerisinde çeşitli değişimlere uğramakta (Bocock, 2014: 52); kapitalist sistemin geçirdiği aşamalar ilgili döneme ait tüketim kültürünü de şekillendirmektedir (Dağtaş ve Dağtaş, 2006: 6-7).

Tüketim kültürü kavramı, bir toplumun sahip olduğu tüketim geleneğini, biçimini ifade etmek için kullanıldığı gibi yalnızca pazar ekonomisinin egemen olduğu toplumlarda var olan bir kültür biçimi anlamında da kullanılmaktadır (Odabaşı, 2013: 41). Pazar ekonomisi ve kapitalist sistemle ilişkilendirilen tüketim toplumunda ürünler birtakım göstergeler ve semboller yolu ile tüketicilere satılmakta, böylelikle ürünün maddi varlığı ve kendisine yüklenen değerler arasında bir bağ kurularak tüketicilere değerlerin satılması söz konusu olmaktadır. Bu bağlamda tüketim, ekonomik içeriğinin yanı sıra sembolik ve kültürel bir içerik de kazanmıştır (Şentürk, 2012: 67).Kapitalizmin aracılarından biri olarak reklam, anlam taşıyıcısı olma özelliği ile tüketicilere tüketim ideolojisini aşılamakta ve birtakım kültürel değerlerin inşasında ve iletiminde de önemli bir rol oynamaktadır. Tüketim kültürü bireylere kendilerini sahip oldukları metalar ve bu metaların sahip oldukları semboller ile ifade etmelerini öğretmektedir (Featherstone, 2013:155). 
Tüketimi bir söylem olarak tanımlayan Baudrillard'a göre (2015: 254) günümüz toplumunun konuşma biçimini, dilini tüketim oluşturmaktadır. Bu bağlamda toplum, kendi içinde iletişim kurabilmek için tüketmeli ve ortak bir tüketim biçimini, dilini paylaşıyor olmalıdır.

Bireyler her geçen gün yaratılan ihtiyaçlarla daha fazla tüketmekte ve tüketim olgusunun gündelik yaşam içindeki yerini büyütmektedir. Bu bağlamda işletmeler de bireylerin tüketim ritüelleri içinde yer almak amacıyla iletişim stratejilerini tüketici odaklı olarak geliştirmektedirler. Ayrıca markalarla tüketicilerin bağ kurması ve sadık tüketiciler yaratılması için tüketim kültüründen beslenerek kültürel ve toplumsal değerlerin bir parçası olma amacıyla tüketicilere ritüel temelli mesajlar iletebilmektedirler.

\section{Ritüel, Ritüel Tüketimi ve Ritüel Yaratan Marka Ilișkisi}

Ritüeller yaşamın içinde kültürden beslenen bir unsurdur. Geçmişten günümüze getirdiğimiz ritüeller kültürel değerlerle birleşerek günlük yaşam içinde önemli bir yer almaktadır. Rook (1985: 252) ritüel kavramının, aralıklı bir biçimde tekrarlanan birden çok davranıştan oluşan sabit, anlamlı ve sembolik bir aktiviteye işaret ettiğini aktarmaktadır. Bu bağlamda ritüeller senaryolaştırılmış bir biçimde resmiyet, ciddiyet ve içsel bir yoğunlukla uygulamaya konulmaktadır. Ritüeller, bireylerin toplum içindeki sosyal kimliklerini pekiştirmektedir. Ritüellerin bir parçası olmak birey için aynı zamanda bir grubun parçası olmak anlamına gelmektedir (Yingfeng, 2011:1334). Bireyler benzer tüketim alışkanlıkları ve benzer ritüellere sahip olan diğer bireylerle paylaşımda bulunmaktan, bir durum veya grubun parçası olmaktan mutluluk duymaktadır. Bu kapsamda Rook (2001:281) ritüellerin bir toplumun veya bir grubun birleşmesine ve bir bütün olmasına katkıda bulunduğunu belirtmektedir. Odabaşı (2013: 74) anlamın üründen tüketiciye aktarımında yer alan ritüellerin veya törenlerin sembolik eylem olarak da adlandırıldıklarını belirterek ritüellerin sosyal bir olay ile gerçekleştirildiklerinin altını çizmektedir. Ayrıca ritüeller, bireylerin maddi nitelik taşıyan ürün ile bağlantı kurmalarını sağlamaktadır.

Literatürde alışkanlık kavramının ritüel kavramı ile karıştırılıyor olmasına dikkat çekilmektedir. Stanfield-Tetreault ve Kleine (1990) ritüel kavramının, alışkanlıktan daha yoğun, daha içsel bir kavram olduğunun altını çizmektedirler. Odabaşı (2013:75) ise ritüellerin toplum tarafından tanımlandıklarını, bireylerin ritüellerde nelerin olacağını bilinçli bir biçimde bildiklerini, bireylerin ritüellere duygusal olarak bağlandıklarını ve ritüellerin alışkanlıklar ile karşılaştıklarında daha sembolik anlamlar taşıdıklarını belirtmektedir.

Toplumsal değişimlerle birlikte ritüeller de değişime uğrayabilmektedir (Üstüner vd. 2000). Ritüellerin dinamik yapısı bireylerin bu ritüellere uyum sağlamasına, ritüellerin modern toplum koşullarına göre değişim göstermesine ve kültürle harmanlanarak şekillenmesine olanak sağlamaktadır. Rook (2001:280) 1800'lerde ritüelin teolojinin hareket dili olarak tanımlandığını belirterek dinde inanış ve ritüellerin önemine dikkat çekmekte; Erdoğan (2006:49) ise Orta Çağ'da kilisenin, vaftiz, dinsel törenler, günlük veya haftalık rutinler, vaazlar gibi ritüeller yolu ile toplumun kontrolünü sağladığını belirtmektedir. Bununla birlikte din, toplumun giderek daha uzağına taşındıkça dinsel birleştiriciliğin ve dini ritüellerin taşıdığı potansiyel, tüketim sağlama amacıyla değerlendirilmektedir (Arık, 2004:85). Tüketim olgusu, markalar için ritüelleşmeyi ve 
ritüel yaratan marka ilişkisini önemli bir eksene yerleştirmektedir. Markalar tüketicilerin ürünlerini tüketme biçimlerinde ritüellere yer vererek marka ile tüketici arasında duygusal bağ kurmayı amaçlamaktadır. Bu bağlamda markalar ile dinin birbirine benzeyen yanları ve markaların ritüelleri değerlendirildiğinde Apple, Nike ve Harley Davidson gibi markalar ön plana çıkmaktadır. Apple markası uzun yıllardır sürdürdüğü iletişim stratejisinde ve ritüel haline gelen tanıtım günlerinde tüketici zihninde güç ve intişamı simgelemekte, Nike tüketici algılarındaki efsanevi simgelerle gizemi ve Harley Davidson da aidiyet duygusunu sembolize etmektedir (Batı, 2015: 293). Tüketici zihninde bu markalara ait tüketim ritüelleri oluşmuştur ve tüketiciler o markayı kullanırken öğrendikleri şekilde tüketmektedir.

Bu kapsamda markaların tüketiciler tarafından kullanım ve tüketim ritüelleri, tüketim ritüelleri olarak adlandırılmaktadır. Günümüzde markalar tüketicilerin ürünü kullanırken uygulamalarını istedikleri ritüelleri kendileri geliştirerek tüketicilere öğretmekte ya da tüketicilerin zaten bildiği toplumsal ritüelleri markalarıyla eşleştirerek markaya özgü algılanmasını sağlamaktadır. Bu bağlamda tüketim ritüeli ürün veya hizmetin sembolik, anlamsal ve duygusal kullanımı ile kültürel ve toplumsal açıdan bir anlam yaratımı olarak tanımlanmaktadır (Otnes\&Lowrey, 2011:xvi).

Literatürde (Rook, 1985; McCracken, 1986; Wallendorf ve Arnould, 1991; Gainer, 1995; Belk, 1990; Levinson vd., 1992; Belk, 1987; McKechnie ve Tynan, 2006; Üstüner, vd., 2000; Kazançoğlu ve Aytekin, 2014; Sandıkçı ve Ömerakı, 2007) tüketim ritüellerine ilişkin çeşitli çalışmalar yer almaktadır. Rook (1985), ritüel deneyimini evren temelli bilimsel çalışmalar, kültürel değerler, grup öğrenmesi, bireysel amaç ve duygular ile biyoloji temelli çalışmalar olarak değerlendirmektedir. Ritüelleri kültürel anlamla ilişkilendiren McCracken (1986) ritüel anlamların kültürel olayların nasıl düzenlendiği, değerlendirildiği ve yapılandırıldığına bağlı olduğunu ve tüketim ürünleri ile transfer edildiğini belirterek reklamların da bu kültürel anlamları ilettiklerini belirtmektedir. Wallendorf \& Arnould (1991) tarafından gerçekleştirilen araştırma sonucunda tüketim ritüelleri ile sosyal yaşam arasında bir ilişki olduğu saptanmıştır. Tüketim ritüelleri ile ilgili araştırma yapan Gainer (1995) tüketim ritüelini sosyal bir ilişki olarak ifade etmektedir. Araştırma sonucuna göre arkadaşlarla paylaşılan bir tüketim ritüeli, marka tercihinde olumlu yönde etkili olmaktadır. Cadılar Bayramı ile ilgili yapılan araştırmaya göre Belk (1990) Cadılar Bayramı ritüellerinin yetişkinlerden çocuklara aktarılan bir ritüel olduğunu belirtmektedir. Aynı zamanda Cadılar Bayramı ile ilgili yapılan filmlerdeki unsurlar da tüketim araçları olarak bireyleri tüketime yönlendirmektedir. Yılbaşı, Cadılar Bayramı, Şükran Günü gibi tüketim odaklı kutlamalarla ilgili etnografik araştırma yapan Levinson vd. (1992) bu tüketim olgusunun temelinde kültürel değerler ve sosyal süreçlerin olduğunu saptamışlardır. Pagan bir kutlama olan Cadılar Bayramı günümüzde modern kutlamalara dönüşerek yeni bir kimlik kazanmıştır. Belk (1987), yılbaşı döneminde bireylerin hediye alıp vererek kendilerini ödüllendirdiklerini ve hediye aldıkları markalarla bir bağ kurduklarını saptamıştır. Yılbaşının temelinde yer alan ritüellere değinen McKechnie ve Tynan (2006) ritüellerin sosyalleşmenin bir aracı olduğuna ve verilen hediyelerle anlamının yansıtıldığına, ancak bu sürecin günümüzde ticarileştiğine değinmektedir. Üstüner vd. (2000) Türk kültürünün bir parçası olan kına gecesi ritüellerinin değişerek anlamlarının yeniden şekillendiğini ve bu değişimin tüketime yansıdığını vurgulamışlardır. Türkiye'de Kazançoğlu ve Aytekin (2014) tarafından gerçekleştirilen araştırmaya göre Sevgililer Günü’ne ait ritüelleri uygulayan tüketicilerin alışveriş merkezlerinde hazcı değerlere göre alışveriş yaptığı saptanmıştır. 
Sandıkçı ve Ömerakı (2007) tarafından gerçekleştirilen bir araştırmaya göre Ramazan Ayı döneminde gerçekleştirilen kutlamalarda yerel özelliklerin yanı sıra küresel izleri de barındıran kutlama ritüellerinin gerçekleştirildiği saptanmıştır. Aynı zamanda Ramazan süresince bazı markaların yapılan etkinliklerde yer alarak bu ritüellerle markalarını eşleştirmeyi hedeflediklerini belirtmektedirler.

Tüketim ritüelleri yalnızca tüketim anında ortaya çıkmamaktadır. Tüketiciler, ilgili tüketim ritüellerini tüketim eyleminden önce, tüketim eylemi esnasında ya da tüketim eyleminden sonra gerçekleştirebilmektedir. Ana tüketim eylemi öncesinde veya sonrasında gerçekleştirilen ritüeller "çevreleyici ritüeller" olarak adlandırımaktadır (Gilde vd., 2011:622). Holt (1992:213) çoğu tüketim ritüelinin kolektivite, resmiyet, tekrarlayıcılık, zaman ve mekan açısından belirli bir kategoriye sahiplik, etkileyicilik, duygusallık gibi özellikler ile karakterize olduğunu aktarmaktadır. Markalar tüketim ritüelleri oluşturmakta ve bu ritüellerin tüketiciler tarafından benimsenmesi için çalışmaktadırlar. Örneğin, Oreo bisküvileri reklamlarında ürünün tüketim ritüelinin önce bisküviyi ikiye ayırmak, kremasını yiyip bisküviyi süte batırarak devamını yemek olduğu gösterilmektedir.

Rook (1985:253) ritüellere dair birtakım öğeler belirlemiştir. Bu öğeler; ritüel eser, ritüel senaryo, rituel roller/uygulamalar ve ritüel izleyici olmak üzere dört tanedir.

Ritüel Eser: Ritüel bir ortamda yer alan veya ritüeller yolu ile tüketilen tüketici ürünleridir. Apple'ın yeni ürünlerini tanıtırken gerçekleştirdiği toplantılar ve tüketicilerin Apple ürünleriyle buluşma anlarına ait ritüeller örnek olarak verilebilmektedir.

Ritüel Senaryo: Ritüel senaryo, ürünün tüketimine dair bir tarif sunmaktadır. Bu senaryoya ürünün kimler tarafından ve nerede tüketileceği de dahildir. Coca Cola'nın önce kendi orijinal bardağına konması, ardından buz eklenmesi, Coca Cola'nın bardağı dökülmesinden sonra limon ile servis edilmesi gibi.

Ritüel Roller/Uygulamalar: Ritüel senaryoyu uygulayanlar, birtakım ritüel roller taşıyan bireylerdir. Örneğin, düğün ve mezuniyet törenlerinde bireyler belirli bir senaryo içerisinde ve bu senaryonun kendilerine atfettiği ritüel roller çerçevesinde yer almaktadırlar. Günümüzde evlilik tekliflerinde erkek kadına pırlanta yüzük vererek evlilik teklif etmektedir.

Ritüel İzleyici: Ritüeller, ilgili ritüel rolleri gerçekleştirenlerin ötesinde daha geniş bir izleyici kitlesine sahip olabilmektedirler. Treise, vd. (1999:19) ritüel izleyici kavramının etkinliği izleyenleri, gözlemleyenleri tanımladığını aktarmaktadırlar. Herkes Harley Davidson motosiklete sahip olmasa da kullanıcıların ritüellerini seyretmekten keyif almaktadırlar.

Bu bağlamda markalar iletişim çalışmalarında bu unsurlara dikkat ederek ritüellerini geliştirmektedirler. Toplumsal ve kültürel değerler, marka ritüelleri yaratım sürecinde ve ritüellerin anlamlandırımasında önemli unsurlar olmaktadır. McCracken (1986:78-80) anlamın, tüketim ürünlerinden tüketicilere aktarımında kullanılan ritüellerisahip olma, değişim, güçlendirme ve yoksun bırakma ritüelleri olarak sıralamaktadır. Sahip olma ritüelleri, satın alınmış bir ürünü tüketileceği yere götürerek onun bireye ait olduğunu 
iddia etmektedir. Temizlik, karşılaştırma, tartışma gibi aktiviteler içermektedir. Değişim ritüelleri hediye almak ve hediye vermek çerçevesinde ele alınmakta ve kişilerarası etki uygulaması olarak kabul edilmektedir. Hediye veren kişi, alıcıya aktarılmasını istediği mesajı seçtiği hediye ile vermektedir. Güçlendirme ritüelleri, kültürel anlamların aktarımı söz konusu olduğunda bu aktarımların tekrarlanması böylelikle anlamların, tüketicinin ve ürünün arasındaki ilişkinin güçlendirilmesi ile açıklanmaktadır. Yoksun bırakma ritüelleri, ürünün önceki kullanıcısına ait anlamların veya kişinin elden çıkardığı ürüne yüklediği anlamların silinmesi amacıyla tüketiciler tarafından kullanılmaktadır (McKechnie ve Tynan, 2006:133).

Marka ritüelleri, pazarlama fırsatı yaratabilmekte, olumlu bir marka ve firma imajı yaratılmasını sağlayabilmekte, tüketim eylemine yönelik bir değer yaratarak tüketim kültürünü destekleyebilmektedir (Yingfeng, 2011).Tüketim toplumu içerisinde birtakım ritüeller yaratılabileceği gibi mevcut ritüellerin içerikleri ve anlamlarında yapılacak değişiklikler ile ilgili ritüeller tüketim ritüellerine dönüştürülebilmektedir (Odabaşı, 2013:75). Markalar, toplumsal bir ritüel içerisinde yer alarak ilgili ritüelleri tüketim çerçevesinde değerlendirebilmektedirler. Sandıkçı ve Ömerakı (2007) 2005 yılında İstanbul'da yapılan Ramazan etkinliklerine değinerek Unilever firmasının bu etkinliklerde yer aldığını, hazır çorbalarının ve bitki çaylarının tanıtımını yaptığını belirtmişlerdir.

Ritüel pazarlaması, markalar tarafından tüketicilere özel ritüeller oluşturularak tüketici zihninde markaya ait bir işaret ve miras değeri yaratma amacıyla gerçekleştirilen pazarlama eylemleridir. Ritüel eylemleri ve marka ilişkisi estetik, yücelik, sembolik ve biçimsel olmak üzere dört unsurdan oluşmaktadır (Yingfeng, 2011:1339). Estetik unsur, ritüel için gerçekleştirilen tören sürecinin estetik değeri olması ve bu süreçten katılımcıların da zevk almasıdır. Oreo bisküvi ve Magnum dondurma yeme ritüeli sürecinde yaratılan estetik unsurlar ve keyif örnek olarak verilebilmektedir. Yücelik unsuru, ritüelin katılımcılara saygı çekiciliği sunmasıdır. Bu unsura Turkcell Platinum üyelerine gösterilen ilgi, bir gruba ait olma duygusu, üye olma süreci ve sonrasındaki ilgilenme süreciyle ilgili ritüeller örnek olarak verilebilmektedir. Sembolik unsur, ritüelin kimlik değeriyle yaratılan ortak bir dil veya sembolik bir eylemi olmasıdır. Örneğin, Harley Davidson markası kullanıcılar için ortak bir ritüel yaratmaktadır. Biçimsel unsur ise ritüel eyleminin sadece uygulama için değil temel olarak anlamı için yapılmasıdır. Örneğin, Hard Rock Cafe yazılı ürünlerin toplum üyelerine aktarılmak istenen anlamı için satın alınması ritüelidir.

Günümüzde pek çok tüketim eylemi ritüel temellidir. Bu nedenle de markalar günlük ritüellerin içinde kendilerine yer bulmak amacıyla pazarlama stratejilerini bu temel çerçevesinde şekillendirmektedir. Örneğin, güzellik ritüeli içinde markalar kadınların günlük rutinleri ve kültürleri içinde yer alan güzellik olgusunu tekrar oluşturmaktadır. Bu çerçevede Oil of Olay Beauty markasının vaadi "Ve gününüz başlıyor. Oil of Olay Ritüeli”dir (Solomon, 2007: 552). Marka, güzellik ve bakım sürecinde kadınların günlük ritüellerinin bir parçası olarak konumlandırılmaktadır.

Ritüeller, markalar tarafından pazarlama fırsatlarının yaratılmasında değerlendirilmektedir. Bu yolla olumlu bir marka ve şirket imajı yaratılması sağlanmaktadır (Yingfeng, 2011). Markalar, kendilerine ait birtakım ritüeller yaratabilecekleri gibi var olan ritüellerin içeriklerinde ve anlamlarında değişiklikler 
yaparak ilgili ritüelleri markanın bünyesine katabilmekte (Odabaşı, 2013:75); bu süreçte ise iletişim çalışmalarından yararlanmaktadır. Markaların gerçekleştirdiği iletişim çalışmalarından biri olan reklamlar, sonsuz sayıda ritüelle donatılarak ürüne, markaya veya ritüelin kendisine ilişkin pek çok anlamın yaratılmasına olanak tanımaktadır (Otnes ve Scott, 1996:34).

Pazarlama stratejileri çerçevesinde markalar tarafından oluşturulan ritüeller, marka topluluklarının da bir araya gelmesinde etken olmaktadır. Bu bağlamda birer toplumsal varlık olan marka toplulukları kendilerine ait normlara, ritüellere sahip olmaktadır (Algesheimer, vd., 2005). Marka tarafından yaratılan öyküler ve ritüeller ile markaya bağlanan topluluk üyeleri, birbirleriyle de bir bağ kurmakta ve aidiyet duygusu hissetmektedirler (Nambisan ve Baron, 2007:47).Günümüzde rekabetin yoğun olduğu pazarlarda markaların rakiplerinden farklılaşabilmesi de ancak marka ile tüketici arasında güçlü bir duygusal bağ kurulmasıyla gerçekleşebilmektedir.

\section{Reklam ve Marka Sadakati Ekseninde Ritüellerin Yeri}

Reklamlar, kaynağını kültürden alan ve ritüeller yolu ile erişilebilir olan dünyevi ve kutsal yönleri bulunan bir semboller sistemi olarak tanımlanmaktadır (Sherry, 1987: 443-444). Kültürel olarak inşa edilmiş dünya, tüketicilere sunulan ürünlerin taşıdıkları kültürel anlamlara ve ritüellere kaynaklık etmektedir. Kültürel dünyada bulunan anlamların aktarımlarında ise reklam önemli bir aracı olarak hizmet vermektedir (McCracken, 1986: 71-72, 74). Geleneksel toplumda ritüellerin aktarım aracı olan masalların yerini günümüz toplumunda reklamlar almaktadır. Ritüel ve reklam arasındaki bu ilişki karşılıklı bir biçimde gerçekleşmekte ve süreklilik taşımaktadır (Otnes ve Scott, 1996: $35,40)$. Ritüeller evrensel mitlerdir ve günümüzde reklamlar aracılığıyla çağdaş ritüeller ve mitler yaratılmaktadır. Reklamlar aracılığıyla marka ritüelleri, tüketicilerin ritüelleri olmakta; tüketicilerin kendi yaşamlarına entegre olarak markaya/ürüne yönelik aşinalık sağlamaktadır (Wertime, 2002: 163).

Ritüeller, reklamlarda ürünlere anlam katmak için kullanılırken aynı zamanda tüketiciler de reklamlardan etkilenmektedirler. Odabaşı (2013: 67-68) reklam, moda ve tüketim ritüellerini anlamın iletiminde birer aracı olarak tanımlamaktadır. Anlamın kültürden tüketim ürünlerine aktarımını reklam ve moda sağlarken tüketim ritüelleri de anlamın tüketim ürünlerinden tüketicilere aktarımını sağlamaktadır. Bu aktarımlar tüketiciler için markaya eğilim talebini de artırmaktadır. Bu bağlamda markalar, marka inşa sürecinde reklamlar aracılığıyla ritüellerini aktarmakta ve marka sadakati yaratmayı hedeflemektedirler.

Pazarlamacılar, marka inşa sürecinin temeline Aaker (1996) ve Morris (1996)'in de belirttiği üzere marka sadakatini oturtmaktadırlar (Fournier, 1997: 451). Tüketicilerin sadık oldukları markalar için daha yüksek miktarda ödeme yapmaya istekli olmaları (Chaudri ve Holbrook, 2001: 81), bu durumun temel nedenini oluşturmakta ve pazarlamacıların marka sadakatinin yaratılmasına verdikleri önemi arttırmaktadır.

Oliver (1999: 34) marka sadakatini bir ürün veya hizmeti yeniden satın almaya yönelik derin adanmışlık hali olarak tanımlamaktadır. Dick ve Basu (1994: 99) tarafından yapılan bir diğer tanımlamaya göre marka sadakati, bir tüketicinin göreceli tutumu ve devamlı müşteri olması arasındaki ilişkinin gücü olmaktadır. Tucker (1964) ise 
marka sadakatini bir markayı arka arkaya üç defa satın almak olarak tanımlamaktadır. $\mathrm{Bu}$ tanımlar çerçevesinde bakıldığında, marka sadakatine ilişkin olarak tekrarlanan satın alma eylemi ve adanmışlık kavramı önem taşımaktadır. İlgili kavramlara marka sadakatinin boyutlarında da rastlanmaktadır.

Marka sadakatinin dayandığı temellere bakıldığında geleneksel görüşe göre sadakat, tüketicilerin markadan memnun olmaları ile ilişkili olmaktadır. Günümüzde memnuniyetin yanı sıra markanın kullanımından doğan deneyimlerin de marka sadakatini ortaya çıkaran önemli bir etken olduğu ifade edilmektedir (McAlexander vd. 2003: 1). Bu bağlamda tüketicilerin markayı kullanım biçimleri ve kullanım biçimlerine bağıı olarak markaya yükledikleri anlamlar da önem taşımaktadır.

Tüketiciler de markaların kendi ritüelleri ve günlük rutinleri içinde yer almalarını tercih etmektedir. Starbucks ve Disney bu çerçevede tüketicinin günlük ritüellerinin bir parçası olarak marka sadakati yaratmaktadırlar. Örneğin, Disney anne ve babaların çocukken seyrettikleri çizgi filmleri onların çocuklarına seyrettirerek ve hatta Disneyland'de çizgi film karakterleriyle karşılaştırarak çocukluk ritüellerini hatırlatma ve kendi çocuklarının da bunların bir parçası olması için bu çizgi filmleri seyretmeye yönlendirmektedir (Cowell, n.d.:14). Bu bağlamda markalar tüketicilere ait ritüellerin bir parçası olmaya çalışırken aynı zamanda kendi ritüellerini de oluşturarak marka sadakati yaratmaktadırlar.

\section{Metodoloji}

Araştırmanın amacı, markaların reklamlarında kullandıkları ritüel olgusunun marka sadakatiyle ilişkisini araştırmaktır. Bu bağlamda öncelikle tüketicilerle marka ritüelleri arasındaki ilişki irdelenirken, ritüellerin marka sadakati yaratma sürecindeki etkisi tartışılmıştır. Ayrıca tüketicilerin marka ritüellerini hangi koşullarda tüketim alışkanlıklarına dönüştürdükleri de araştırma kapsamında değerlendirilmiştir.

Araştırma, tüketicilerin ritüellerle ilgili bakış açılarını kavrayabilmek amacıyla odak grup yöntemiyle gerçekleştirilmiştir. 1950'li yıllardan sonra ön plana çıkan odak grup görüşme yöntemi günümüzde sosyal bilimlerdeki araştırmalarda tercih edilen bir tekniktir. Odak grup çalışmaları iletişim alanında ilk olarak Lazarsfeld ve Merton tarafından radyo ve televizyon programları araştırmaları için kullanılmış ve günümüzde iletişim, pazarlama, marka algıları gibi alanlarda tercih edilen bir teknik olmuştur (Steward ve Shamdasani, 2015:7).

Odak gruplar seçilmiş katılımcıların yer aldığı ve moderatör tarafından yönlendirilen küçük, yapılandırılmış grupla olmakta belirli bir konu hakkında, bireylerin görüşlerinin ve deneyimlerinin paylaşılması, grup etkileşiminin sağlanması hedeflenmektedir (Litosseliti, 2007: 1). Odak grup çalışmalarında katılımcı sayısı ile ilgili farklı görüşler olmasına rağmen, genellikle bu çalışmaların 4 ile 10 kişi arasında az sayıda katılımcı ile gerçekleştirilmesi gerekmekte ve 10-15 arasında soru sorulmaktadır (Çokluk, 2011:100,102).

Araştırma kapsamında gerçekleştirilen odak grup görüşmesinde yarı yapılandırılmış sorular yöneltilmiştir. Öncelikle araştırmada kullanılacak soruların uygun olup olmadığını saptayabilmek amacıyla toplam 3 kişiden oluşan bir gruba pilot görüşme yapılarak 
sorular irdelenmiştir. Bu pilot çalışma sonrasında sorular tekrar düzenlenerek odak grup görüşmesine hazırlanıımıştır. Toplam 3 odak grup çalışması gerçekleştirilmiştir. Odak grup görüşmelerine başlamadan önce katılımcıların demografik bilgilerinin belirlenmesi amacıyla demografik bilgilerin yer aldığı bir form doldurmaları istenmiştir. Ardından odak grup görüşmesi başlatılmıştır. Odak grup görüşmelerinde açık uçlu ve yoruma uygun olan toplam 9 soru yer almaktadır. İlk bölümde ritüellerle ilgili genel sorulara, ikinci bölümde ritüel yaratan markalar ve reklam ilişkisi ile ilgili sorulara yer verilirken üçüncü bölümde katılımcılara ritüel pazarlaması ve marka sadakati ilişkisi ile ilgili sorular yöneltilmiştir. Odak grup görüşme sorularının oluşumunda McCracken'ın (1986) ve Keller'ın (2001) çalışmalarından yararlanılmıştır. Odak grup görüşmeleri sonucunda çok geniş bir grubun fikri alınmadığı için odak grup sonuçlarını katılımcıların görüşleri bazında değerlendirmek daha doğrudur. Ayrıca odak grup görüşmelerinde her bir gruba aynı sorular sorulmasına karşın grup dinamiklerindeki değişimler nedeniyle sorulara yaklaşımlar farklılaşmaktadır (Fern, 2001:121).

Araştırma kapsamında örneklem, amaçsal örneklem yöntemi ile seçilen katılımcılardan oluşmaktadır. İlk odak grup çalışmasında 6, ikinci odak grup çalışmasında 5 ve üçüncü odak grup çalışmasında 8 katılımcı yer almaktadır. Odak grup görüşmeleri toplam 19 katılımcıyla 15 Nisan 2016-4 Mayıs 2016 tarihleri arasında İzmir'de gerçekleştirilmiştir. Odak grup görüşmesi süresince ses kayıt cihazı görüşmeyi kaydetmiştir. Odak grup görüşmelerinin her biri 60-90 dakika arasında gerçekleşmiştir. Katılımcılar U masa düzenine göre yerleştirilmiş böylece tüm katılımcıların birbiriyle etkileşime girmeleri sağlanmıştır. Odak grup katılımcılarına öncelikle ritüellerle ilgili genel bir açıklama yapılarak konuya hazırlık yapılmıştır. Odak grup sonrasında ses kayıt cihazındaki görüşmeler deşifre edilmiştir. Deşifre işlemi yazarlar tarafından gerçekleştirilmiştir. Sorulara verilen cevaplar araşıırma sorularına göre gruplandırılmıştır. Bu amaç çerçevesinde belirlenen araştırma soruları şu şekildedir:

Araştırma Sorusu 1: Tüketiciler ritüelleri yaşamlarının bir parçası olarak görmekte midir?

Araştırma Sorusu 2: Marka ritüelleri ile kültür arasında bir ilişki var mıdır?

Araştırma Sorusu 3: Ritüeller marka tercihinde ve tüketim şeklinde etkili

midir?

Araştırma sorusu 4: Ritüeller marka sadakati yaratma sürecinde etkili midir?

Araştırma kapsamında sınırlılıklar vardır. Bu araştırma kapsamında en temel sınırlıık ritüel yaratan markalarla ilgili olarak Türkiye'de yaşayan ve ritüellere değer veren herkese ulaşılamamış olmasıdır. Ayrıca ritüel yaratan marka teriminin henüz yeni bir terim olması nedeniyle farkındalığın az olması ve kavram karmaşası olması bir diğer sınırlılıktır. Bu çalışma kapsamında odak grup görüşmesi yapılmış ve daha geniş bir kitlenin görüşlerini almak amacıyla anket uygulanmamış olması da bir diğer sınırlılıktır.

\section{Bulgular}

Katılımcıların sosyo demografik özellikleri incelendiğinde gerçekleştirilen toplam 3 odak grup çalışmasında toplam 10 kadın, 9 erkek katılımcı yer almıştır. Katılımcıların yaş aralığı incelendiğinde 21 ile 59 yaş aralığı arasında değişen katılımcı yaşlarının ortalaması 31,52'dir. Medeni durum olarak irdelendiğinde 8 katılımcı evli, 11 katılımcı bekardır.5 katılımcı lisansüstü mezunu, 6 katıımcı lisans mezunu, 8 katılımcı lisans 
öğrencisi iken 8 katılımcı öğrenci, 11 katılımcı özel sektör çalışanıdır. 4 katılımcı üst gelire, 8 katılımcı orta üst gelire ve 7 katılımcı da orta düzeyde hane gelirine sahiptir. Sosyo demografik veriler incelendiğinde odak grup görüşmelerinde farklı demografik gruplardan katılımcıların orantısal bir şekilde yer aldığı görülmektedir.

\subsection{Marka ve Ritüel Illișkisi}

Markalar, var olan ritüellerin bir parçası olmak veya bir ritüel yaratarak tüketicilerin tüketim alışkanlıkları içine bu ritüelleri yerleştirmek için iletişim stratejileri geliştirmektedirler. Bu bağlamda kahve kokusu ile uyanarak güne başlamak, hazır kahvenin bir seremoni ile hazırlanması ve tadımı Türk kültüründe geçmiş yıllarda yer almıyorken, reklam mesajlarıyla iletilmesi sonucunda bir ritüel oluşmuştur. Ayrıca Oreo bisküvilerinin sadece paketi açılarak yenilmesi yerine önce ikiye bölünmesi sonra kremasının yenilmesi, bisküvinin süte batırılarak yenilmesi ritüelini getirmiştir. Bu örnekler çoğaltılabilmekte ve tüketiciler her geçen gün farklı markalar tarafından yaratılan tüketim ritüellerine maruz kalmaktadır.

Araştırmada "Tüketiciler ritüelleri yaşamlarının bir parçası olarak görmekte midir?" sorunsalına cevap aranmıştır. Bu kapsamda katılımcıların bu konuyla ilgili görüşlerini almak amacıyla "Sizce markalar ritüeller yaratıyor mu?" ve "Markaların gündelik yaşam içinde yer alan ritüeller yaratması hoșunuza gidiyor mu?" soruları yöneltilmiştir. Bu bağlamda tüm katılımcılar markaların bir şekilde ritüel yarattıklarını ifade etmişlerdir. Ancak 13 katılımcı markaların gündelik yaşam içinde ritüel yaratmasına olumlu yaklaşırken 6 katılımcı olumlu yaklaşmamıştır.

Literatürde de ifade edildiği üzere ritüel pazarlamasının temelinde yer alan markaların, tüketicilerin zihninde markaya ait bir işaret ve miras değeri oluşturma yaklaşımıyla yarattıkları ritüellerin katılımcıların kendilerini özel hissetmelerini ve markanın duygularına seslenmesiyle geçmiş, anılar gibi değerlerle örtüşmesini sağladığı belirtilebilmektedir. Günümüzde markaların ritüel yaratma çabaları arasında yer alan markayla tüketici arasında bağ kurulmasının, toplumsal değerlerle marka arasında bir iliş̧ki olmasının, markaya ait bir rutinin tüketici için önemli ve özel olmasının katılımcıların çoğunluğu için de önemli olduğu saptanmıştır. Literatürde yer alan, ritüellerin toplum tarafından tanımlandıkları ve ritüellerin alışkanlıklar ile karşılaştııılıklarında daha sembolik anlamlar taşıması (Odabaşı, 2013:75) katılımcılar tarafından da belirtilerek geçmişe özlem, kendini özel hissetme gibi ifadelerle açıklanmıştır. Olumlu yaklaşan katılımcılardan bazılarının görüşleri şu yöndedir:

Katılımcı 5: Markaların bizim unuttuğumuz, zihnimizin arka planında kalan birtakım kültürel öğeleri, çocukluğumuza ait, geçmişimize ait birtakım ritüelleri tekrardan gündeme getirmesini, o anılarımızı canlandırmasını, bizi geçmişe götürmesini seviyorum. Gündelik yaşamım içinde markanın ritüellerini de uyguluyorum. (Erkek, 30, Evli, Orta Gelir)

Katılımcı 15: Hayatımızın her noktasında farklı ritüeller var, farklı etmenlerle oluşan bu ritüeller markaları da kullanarak bizi birçok açıdan etkiliyor, özellikle de satın alma kararlarımız açısından etkiliyor. Starbucks sayesinde kahve dükkanında kahve içmek sadece ürüne duyulan ihtiyaç ve bir kahve değil, beraberinde karton bardağa yazılan isim, kasada sohbet edilmesi, 
isminizle seslenilmesi, kahve tadımları sayesinde kendini özel hissetme intiyacını karşılıyor.(Kadın, 23, Bekar, Orta gelir)

Katılımcı 19: Markaların ritüellerini hayata geçirmek bana keyif veriyor. Bu ritüeller hem dikkat çekici hem de yaşam içinde kendimi ifade ettiğim anlar oluyor. (Erkek, 49, Evli, Orta Üst Gelir).

Ritüel yaratan markaların gündelik yaşamda tüketim ritüelleri içindeki durumlarıyla ilgili olumsuz görüşe sahip katılımcılardan bazılarının görüşleri şu şekildedir:

Katılımcı 2: Reklamlarda ritüellerle ilgili unsurlar izleyince hoşuma gitse de beni etkilemiyor. Sadece reklamı izlerken bir hoşnutluk veriyor bana, ancak günlük yaşam içinde bu ritüeli kendi yaşamıma yansıtmam. (Kadın, 36, Evli, Orta Üst Gelir)

Katılımcı 3: Ritüeller dinsel bir olgu, bağımlılık yaratan bir şey gibi geliyor bana. Örneğin Coca-Cola kendi bardağında, soğuk, asitli, limonla buzla içilmesi ritüelini ve herkeste yarattığı bu bağımlılığı seviyorum. Çünkü o ritüelin içim kalitesi ile ilgili durum şey olduğunu düşünüyorum. Soğuk içilmesi gerekiyor yani ama onun soğutulması bir ritüel midir ve bunu bir ritüel olduğunu bildiğim için mi yapıyorum ona emin değilim. (Erkek, 52, Bekar, Orta Üst Gelir)

Katılımcı görüşleri irdelendiğinde katılımcılar için ritüellere karşı doğrudan bir olumsuz görüş olmamasına karşın ritüel yaratan markalara karşı sadece ritüel yarattığı için bir ilgi bulunmamaktadır. Ritüel yaratan markaların yaptıkları iletişim çalışmaları ise dikkatlerini çekmekte, ancak bu durum satın alma davranışı veya marka sadakati boyutuna ulaşmamaktadır. Bazı durumlarda katılımcıların markanın kullanım özelliği ile ritüeli aynı anlamda değerlendirmedikleri ve ürünün yapısı gereği olması gereken bir özellik olarak ifade ettikleri saptanmıştır.

\subsection{Marka Ritüellerinin Kültüre Yansıması}

Günümüzde küreselleşme ve benzeri sebeplerle kültürler birbirinden etkilenmekte ve kültürel yapılarda değişimler yaşanmaktadır. McCracken'a göre (1986) tüketicilere sunulan ürünlerin taşıdıkları kültürel anlamlara ve ritüellere kaynaklık eden kültürün aktarımında reklamlar önemli bir araçtır. Markalar kültürün bir parçası olmak ve toplumsal değerler içinde yer almak için iletişim stratejileri geliştirmektedir. Bu süreç içinde reklamlar kültürel değerlerin iletimi ve inşasında etkin bir rol oynamaktadır. Ritüele benzer özellikler taşıyan gelenekler, kültürel kalıntılar olarak ifade edilirken ritüeller de kültürel unsurları barındırmaktadır.

$\mathrm{Bu}$ başlık altında "Marka ritüelleri ile kültür arasında bir ilişki var mıdır?" sorusu irdelenmiştir. Bu bağlamda marka ritüellerinin kültüre yansımasıyla ilgili bilgi almak amacıyla odak grup katılımcılarına "Sizce marka ritüelleri kültürün bir parçası mıdır?" ve "Markaların yarattığı ritüeller kültürel bir unsur oluşturabilirler mi?" diye sorulmuştur.

Katılımcılar genel olarak marka ritüellerinin kültüre yansıdığı ve marka ritüellerinin kültürü az veya çok etkilediği görüşündedirler. Aynı zamanda reklamların da bu 
ritüelleri oluşturmada ve kültüre aktarmada etkili olduğu belirtilmektedir. Bu görüşleri özellikle reklamların etkileyebilme gücüyle ve ritüellerin bireyler üzerinde bir alışkanlık sağlamaları nedeniyle günlük yaşama ve kültürel öğelere yansıtmalarına bağlamaktadırlar. Katılımcılardan gelen cevaplardan elde edilen verilere göre markalar ancak Türk kültürünü tanıyarak yeni bir kültürel unsuru adapte edebilmektedir. Özellikle markanın ritüeller aracılığıyla aktardığı kültürde toplumu tanıması, global markalar açısından ritüellerini yerelleştirmeleri önem kazanmaktadır. Katılımcılar kendilerine yakın gelen markaların ritüellerini kolaylıkla benimsemekte ve kültüre yansıtılmasına da olumlu bakmaktadırlar. Ancak bu süreçte markanın hedef kitleyi tanıması ve toplumsal değerlerle entegre edilebilecek kültürel unsurları aktarması büyük önem taşımaktadır. Ritüellerin kültüre yansıdığı görüşlerine ek olarak katılımcı 5, 7, 10, 17 ve 18'in cevapları aşağıda aktarılmaktadır:

Katılımcı 5: Kültür, marka, ritüel... Aslında marka bir vaattir. Dolayısıyla kültürel öğeleri, o kültüre ait öğeleri sahiplenme çabasının altında da belki kendini böyle köklü hale getirme daha yerleşik ve kalıcı hale getirme çabası vardır. Hem tüketici ile aralarında daha farklı bir bağ kurabiliyorlar hem de o kültürel öğeleri sahiplenerek belki biraz daha kalıcı ve oraya ait olarak kendilerini konumlandırıyorlar. Ama bunu her yaptıklarında da aynı keyfi vermiyor. (Erkek, 30, Evli, Orta Gelir)

Katılımcı 7: Nescafe reklamında sabah güne başlarken Nescafe içiliyor. $O$ bence artık kültürümüzün bir parçası oldu ve kültürümüzle bağdaştı. Sabah kalktığımda kokusuyla beni uyandıran bir acı kahveyle güne başlıyorum ya da akşam yağmur yağarken bir Nescafe içiyorum. (Erkek, 24, Bekar, Orta Üst)

Katılımcı 10: Starbucks'ın bir ritüeli var ve bu ritüelde Türk kültürüne bence ayak uyduruyorlar. Mesela yurtdışında Starbucks'larda çok fazla oturulmuyor ama bizde uzun süre oturuluyor. Çünkü biz Türk toplumu olarak oturmayı çok seviyoruz. O anlamda ritüelleri benimseme olarak hem biz onlara uyum sağlıyoruz hem onlar bize uyum sağlıyorlar. Belli bir yaş geçtikten sonra ritüelleri öğrenmenin daha zor olduğunu düşünüyorum. O yüzden bir kültüre uyarlamanın gençler aracılığıyla yapılması daha kolay diye düşünüyorum. (Kadın, 23, Bekar, Orta Üst Gelir)

Katılımcı 17: Daha önce bizim bildiğimiz evlilik teklifi farklı yapııırdı. Altın alyans vardı hayatımızda. Pırlanta, tek taş daha sonra geldi. Ama Atasay "Beni şu kadarcık sevsen" diye bir reklam kampanyası yaptı. Tek taş pırlanta yüzüğü bizim Türk kültürümüze taşıdı. Artık pırlanta Türkiye'de bir evlilik geleneği haline geldi. (Kadın, 33, Evli, Üst Gelir)

Katılımcı 18: Evet ritüeller kültürün ve yaşamın bir parçasıdır. Markaların oluşturduğu ritüeller de artık aynı derecede bizim hayatımızın ortasında. Bu ritüelleri reklamlardan görerek nasıl hayata geçireceğimizi görüyoruz. Ürünü her kullandığımızda gördüğümüz ve öğrendiğimiz ritüelleri de uygulamamı bunu sunan markaları benimsememizde bir etken oluyorlar. Marka yarattığı ritüel sayesinde ürünü benimsememize katkı sunuyorsa, aynı şekilde bu ürünle beraber alıştığımız ritüeller ortaya çıkıyor. (Erkek, 44, Evli, Orta Üst Gelir) 
Marka ritüellerinin kültürün bir parçası olup olmamasıyla ilgili yöneltilen sorulardan elde edilen bulgulara göre tüketicilerin marka ritüellerine önem vermekte oldukları ve kendilerine yakın gelen markaların ritüellerini reklamlardan görerek kendi yaşamlarına uyarladıkları belirlenmiştir. Ancak elde edilen bulgulara göre ritüel yaratan markaların benimsenme süreçlerinde özellikle kültürel unsurların yerel değerlerle bütünleştirilmesinin önemli olduğu ortaya çıkmıştır.

\subsection{Reklamlar ve Ritüel Tüketimi}

Tüketim ritüeli olarak ifade edilen kavram temelde sosyal bir ilişki olarak saptanmaktadır (Gainer, 1995). Özellikle yaratılan marka ritüelleri tüketim ritüellerini desteklemekte, o markayı tüketenler tarafından kullanılmakta ve bu süreçte markalarla tüketicileri yakınlaştırmaktadır. Bu bağlamda markalar, tüketim ritüeli oluşturabilmeleri amacıyla tüketicilerine reklamlar aracılığıyla mesaj aktarmakta ve anlam taşıyıcısı olmaktadır. Günümüzde markalar gelenekselleşen ritüelleri modern çağa uyarlamakta ve kendi tüketim ritüelleri ile harmanlayarak yorumlamaktadır. Bu süreçte önemli bir yol gösterici olan reklamlar, markanın ritüellerini tüketicilere öğreten önemli bir aktarım aracı olmaktadır.

Reklamlar ve ritüel ilişkisinin değerlendirilmesi kapsamında "Ritüeller marka tercihinde ve tüketim şeklinde etkili midir?" sorusu irdelenmiştir. Bu bağlamda markalara ait tüketim ritüellerinin reklam ve tüketicilerle ilişkisinin irdelenmesi amacıyla odak grup katılımcılarına "Ritüel oluşturmak için reklam yapan markalar dikkatinizi çekiyor mu?" ve "Siz de bu markayı tercih ettiğiniz zaman tüketim öncesinde, tüketim sırasında veya tüketim sonrasında reklam mesajlarında aktarıldığı tüketim ritüellerine uygun davranıyor musunuz?" soruları yöneltilmiştir.

Bu sorulara verilen cevaplar çerçevesinde reklam ve markaya ait yaratılan tüketim ritüeli arasında bir ilişki olduğu ve reklamların dikkat çektiği bulgular arasında yer almaktadır. 15 katılımcı reklamlarda gördükleri ritüellere ait mesajlara olumlu yaklaştıklarını ve ritüelleri tüketimlerine de yansıttıklarını belirtmiştir. Bu bağlamda markaların özellikle ses, koku, tat gibi duyulara hitap eden ritüelleri sahiplenmesinin tercih sebebi olduğu saptanmıştır.

Katılımcı 1: Reklamlarda gördüğüm ritüeller dikkatimi çekiyor. Ama ritüellere birebir sadık kalmıyorum. (Kadın, 59, Evli, Üst Gelir)

Katılımcı 9: İlgi alanıma giriyorsa tabii ki çekiyor. Oreo reklamında mesela çocuklara yönelik yapmışlar o yüzden benim ilgimi çekmiyor. Yaşla da ilgili o reklamın kime hitap ettiğiyle de ilgili. (Kadın, 26, Bekar, Orta Gelir)

Katılımcı 13: Bir marka ve reklam dikkatimi çekiyorsa o marka ve o kullanım biçimini denerim.(Kadın, 23, Bekar, Orta Gelir)

Markaların ritüellerini katılımcıların uyguladıkları saptanmıştır. Bazı katılımcılar markaların ritüellerini yaşamlarına bilinçli olarak yerleştirmektedir. Bazıları ise görerek, takip ederek veya zaten var olan davranış kalıplarını markalarla eşleştirerek bir şekilde yaşamlarının bir parçası haline getirmişlerdir. 
Katılımcı 5: Ben de kesinlikle etkilendiğimi söyleyebilirim çünkü ben bu ritüelleri biraz kültürel kullanım kılavuzu gibi görüyorum. Bir yemek nasıl yenir, nasıl tüketilir. Özel bir gün olduğunda bir şeye nasıl tepki verilir. Bunlar zamanla bazı şeylerin yapılışını ritüel haline dönüşebiliyor. Yani benim ürünümden en iyi bu şekilde faydalanırsın en iyi bu şekilde tat, lezzet alırsın mesajı vermeye çalışıyorlarmış gibi geliyor. Coca-Cola'nın limon ile belki hakikaten tadı çok güzel oluyordur. (Erkek, 30, Evli, Orta Gelir)

Katılımcı 18: Ritüel oluşturan markaların bu reklamları, özellikle ritüel oluşturduğu için dikkatimi çekmeyebilir. Oluşturulan ritüel yaratan markanın kimliği, ürünün özellikleriyle doğru özdeşleşmişse ve etkili iletişim sayesinde oluşturulan ritüeli benimsememi sağlayabilir.(Erkek, 44, Evli, Üst Orta Gelir)

Katılımcı 16: Ritüel ve marka ilişkisini seviyorum. Bir markayı görünce otomatik pilota alıp markanın tüketim ritüellerini uygulamayı seviyorum. Mesela Apple markasını ve ritüellerini çok seviyorum. Bana markanın bir ruhu varmış gibi geliyor.(Erkek, 42, Evli, Üst Orta Gelir)

Reklamlarda yer alan ritüeller odak grup katılımcılarının dikkatini çekmektedir. Ancak katılımcılar için hedef kitle olup olmamak ayırt edici bir durum olmaktadır. Her markanın ritüelinin dikkat çekmediği, hedef kitleye seslenen markanın reklam mesajlarındaki ritüellerin tüketicilerin dikkatini çektiği saptanmıştır. Ancak katılımcılar arasında ritüelleri tüketimlerine yansıtıp yansıtmama durumu değişiklik göstermektedir. Özellikle genç yaş grubunda yer alan katılımcıların bazılarının reklamlara dikkat etmelerine karşın reklamda gördükleri ritüelleri yaşamlarına aktarmadıkları görülmüştür.

Katılımcı 10: Bir ritüel ilk başladığında çok etkili olmuyor ama kampanyanın devamıyla uzun bir süreçte etki edebiliyor. İşe yarıyor bence, reklamlar dikkatimi çekiyor ama ben kullanmıyorum.(Kadın, 23, Bekar, Orta Üst Gelir)

Katılımcı 12: Ben öyle reklamda gördüm diye denemem. Örneğin Oreo'yu alıp ikiye bölüp süte batırmam özellikle reklamda görüp ben de yapayım demem. (Erkek, 25, Bekar, Üst Orta Gelir)

Bir diğer yandan katılımcılar arasında dikkat çeken görüşler yer almaktadır. Özellikle ritüel yaratan markaların geçmişle bağ kurdukları ve bu nedenle anıları canlandıran ritüel yaratan markaların tüketimlerinin de bu yönde olduğu saptanmıştır. Ritüellerinde geçmişe seslenen ve tüketicilerin anılarıyla marka ritüellerini eşleştirebilen markaların daha dikkat çekici olduğu ve ritüellerinin daha kolay benimsendiği ortaya çıkmıştır.

Katılımcı 4: Reklam değil ama yaşanmışlık üzerinden bir bağ oluşturması önemli benim için. Ben eski filmlerin hastasıyım. Özellikle Sadri Alışık hastası olarak Çaykur reklamını gördüğümde Çaykur aldım. Çayın da ritüellerini yansıtıyor, geçmiş günleri, çocukluğumu. Eskiden evler çay kokardı. Çaykur'un çay ritüelleri ile yine o kokuyu duyuyormuşum gibi geliyor. (Kadın, 37, Bekar, Orta Gelir)

Bu bağlamda ritüel yaratan markalarının reklamlarının katılımcılar tarafından dikkat 
çekici bulunduğu ve takip edildiği belirtilebilmektedir. Ayrıca marka ritüellerinin tüketim ritüellerine dönüştüğü ve eğer hedef kitleye mesaj doğru iletiliyorsa hedef kitlenin bu ritüelleri uyguladığı saptanmıştır. Ancak gençlerin reklamda gördükleri ritüelleri tüketim ritüellerine dönüştürmelerinin orta yaş ve üzeri katılımcılara göre daha az olduğu saptanmıştır. Aynı zamanda ritüel yaratan markaların duyulara hitap etmesinin tüketim ritüelleri açısından fark yaratıcı olduğu belirtilebilmektedir.

\subsection{Ritüel Markalarına Yönelik Marka Sadakati}

Markalar için sadık tüketiciler yaratmak öncelikli bir hedeftir. Bu bağlamda iletişim stratejilerinin temelinde markayla tüketici arasında güçlü bir bağ kurma amacı bulunmaktadır. Markalar tüketicilere yaşamlarında o markayla eşleşen bir ritüel sunarak marka sadakati yaratmaktadır. Türk kültüründe geçtiğimiz yıllara kadar yer almayan her sabah kahve almak için kahve dükkânına uğranması rutinini Starbucks kendi ritüellerini yaratarak yerleştirmiş ve sadık bir tüketici grubu kazanmıştır.

Araştırma kapsamında "Ritüeller marka sadakati yaratma sürecinde etkili midir?" sorusu incelenmiştir. Bu bağlamda ritüel yaratan markalar ve marka sadakati ilişkisini irdelemek amacıyla katılımcılara "Yaşamınıza bir ritüel katan markalar, kalbinizde diğer markalardan daha farklı ve özel bir yere sahip midir?" "Kendinizi ritüel yaratan markalara yönelik sadık hissediyor musunuz?" ve "Eğer ritüel pazarlaması yapan bu marka olmasaydı yerine başka bir marka koymakta zorlanır mıydınız?" soruları sorulmuştur.

Bulgulara göre odak grupta yer alan 14 katılımcı marka sadakati ve marka ritüelleri arasında bir ilişki olduğunu belirtirken 5 katılımcı ritüellerin marka sadakati yaratma sürecinde etkili olmadığını belirtmiştir. Katılımcıların markanın bilinçaltına seslenmesi ve markayla bağ kurma sürecinde etkili olması gibi sebeplerle ritüellere olumlu yaklaştıkları saptanmıştır. Özellikle ritüellerin bir markaya ait bir ritüel olarak değil, tüketicinin yaşam tarzıyla bütünleşen doğal bir süreç olmasının marka sadakati yaratımında etkili olduğu saptanmıştır. Bu bağlamda bu bulgunun literatürde de aktarılan marka sadakati ve ritüel ilişkisi bilgileriyle örtüştüğü belirtilebilmektedir. Odak grupta marka sadakati ve marka ritüelleri arasında bir ilişki olduğunu belirten katılımcılardan dikkat çeken cevaplar şu şekildedir:

Katılımcı 17: Bence pek çok kişi markayla bağ kuruyordur. Artık günümüzde alışverişe gidince karşınıza benzer ürünler çıkıyor. Hangi ürünü seçeceğiniz duygularla, bazen ritüellerle, bazen de bir renkle olabiliyor. Mesela Kent çikolata reklamları bizim bayramlarda beraber olma geleneğimizi sahipleniyor ve ritüelleştiriyor. O markayla bağ kurup o markayı tercih ediyorum. (Kadın, 33, Evli, Üst Gelir)

Katılımcı 3: Reklam değil ama yaşanmışlık üzerinden bir bağ oluşuyor daha çok yani. Marka bir bağlılık yaratabiliyor. Kendi ritüelinin bir parçası haline gelebiliyor. Onun yarattığı ritüel değil de senin ritüelinin bir parçası haline gelebiliyor.(Erkek, 52, Bekar Orta Üst Gelir)

Katılımcı 15: Sadakat duyarım. Bu markaların sadece ürünün lezzeti, yeniliği gibi özelliklerinden öte sunduğu başarılı ritüeller sayesinde marka 
kimliğine katkıda bulunduğunu düşünüyorum. Örnek vermek gerekirse, Oreo benzeri bunca bisküvi varken, hepsinin içlerinden Oreo'nun özel bir yeme şekli sunuyor olması, bu bisküvinin diğerlerine göre daha farklı, hatta belki daha özel olduğunu algılamamı sağlıyor. Sunulan bu ritüel, Oreo'ya bisküviden öte bir kimlik kazandırıyor. (Kadın, 32, Bekar, Orta Gelir)

Ritüel ve marka sadakati ilişkisine olumlu bakılmasına karşın bazı katılımcılar bu sadakatin sadece ritüel yaratarak uzun süreli olamayacağı görüşündedir. Özellikle markaların değişime intiyacı olduğu görüşü ön plana çıkmaktadır. Bu değişim sürecinde de ritüellerin değişimin bir parçası ve belki de öncüsü olması önem kazanmaktadır. Bu görüşlerden bazıları şu şekildedir:

Katılımcı 10: Bence ritüeller insanları zaman zaman etkileyebiliyor. Bir Coca-Cola gibi ritüeli yakalayabilmek zor bir şey. Belli bir zaman içinde tüketicilerin ilgilerini çekebiliyor. Ama bunun çok uzun vadeli olmadığını düşünüyorum. (Kadın, 23, Bekar, Orta Üst Gelir)

Katılımcı 19: Gençliğimde kullandığım ürünler vardır, bana o günleri hatırlatır. O dönemde bana sadece o markayı ve onun ritüellerini kullanacakmışım gibi gelirdi. Ancak zamanla zevkim, yaşam biçimim değiştikçe artık o markaları kullanmamaya başladım. Bence ritüel, marka sadakati yaratmada önemli; ama sonsuza kadar hayatımda kalmasını sağlar mı ona emin değilim. Markanın yeni duygular, yeni heyecanlar katması gerekiyor yaşamıma. Eğer ritüeller bu değişime ayak uydurabilirse sadakatim ve ilgim devam edebilir. (Erkek, 49, Evli, Orta Üst Gelir)

Ritüellerin marka sadakati yaratmadığı görüşünde olan katılımcılar, markayla duygusal bağ kurmanın ve markanın sadık bir tüketicisi olmasının nedeninin ritüeller olmadığı görüşündedir. Bu görüşteki katılımcılar, markaların ritüellerinin benzer kategorideki diğer markalara da uyarlanabileceğini belirtmektedirler. Bu nedenle ritüeller üzerinden marka sadakati iddiasına olumlu yaklaşmadıkları saptanmıştır. Ancak ritüellerin marka sadakati yaratmasalar da markaya yönelik olumlu duygular beslenmesini sağladığı bulgular arasındadır. Bununla birlikte ürünün fonksiyonel özellikleri ritüel yaratımının önüne geçebilmekte ve öncelikle ürün kalitesi, işlevi gibi özellikler ön planda olabilmektedir.

Katılımcı 6: Ben direkt olarak o marka ritüeli yaptı diye değil, işte aynı ürün kategorisinde farklı kendi sevdiğim bir markayla da onu özdeşleştirebiliyorum.(Kadın, 28 Bekar, Orta Gelir)

Katılımcı 12: Bende bir marka bağlılığı olacaksa ritüelle alakası olmaz. Tadını sevdiğim için bir ürün alırım. Ya da telefon için dayanıklıysa, kullanımı rahatsa gidip tekrar onu alırım.(Erkek, 25, Bekar, Orta Gelir)

Bu bulgular çerçevesinde katılımcıların çoğunluğu marka ritüellerinin marka sadakatini etkilediği görüşüne sahiptirler. Özellikle marka çağrışımlarının ritüel tüketimler aracılığıyla olumlu şekilde yapılandırıldığı ve tüketicilerin bilinçaltına olumlu mesajlar iletildiği, böylece marka sadakati yaratım sürecinde ritüellerin etkili olduğu saptanmıştır. Marka ritüellerin özellikle tüketici yaşam tarzıyla birleştirilmesi ve yaşama entegre 
edilmesi önemlidir. Her ne kadar bu katılımcılardan bazıları marka sadakati yaratım sürecinde ritüelleri olumlu bir unsur olarak değerlendirdiyse de marka ritüellerinin yeterli ve uzun dönemli bir marka sadakati yaratım sürecinde etkili olmadığını belirtmişlerdir. Bu bağlamda zamanla marka ritüellerinin de değişmesi ve yenilenmesi gerektiği fikri ortaya çıkmıştır. Marka ritüellerinin marka sadakatini etkilemediği görüşünde olan katılımcılar, markaların rakiplerine de bu ritüellerin uygulanabileceğini düşünmektedirler. Bu nedenle ritüel yaratan markaya yönelik ritüel kaynaklı bir sadakat yaratımının mümkün olmadığı saptanmıştır.

\section{Sonuc}

Dini ve toplumsal kökenlere dayanan düzenli uygulamalar olan ritüeller, toplum içerisinde veya belirli gruplar arasında bağ kurma açısından da önem teşkil etmektedir. Uluslararası literatür incelendiğinde tüketim ritüelleri ve reklam alanında araştırmalar yapılmış olsa da Türkiye'de tüketim ritüelleri ve reklam çerçevesinde çalışmalar reklam kültür ekseninde irdelenmiştir. Tüketim ritüelleri üzerine 1980 'ler itibari ile pek çok çalışma yapıldığı görülebilmektedir. Yingfeng'e (2011) göre ritüellerin bir parçası olmak birey için bir aidiyet hissi yaratmaktır. Bu nedenle bireylere benzer tüketim alışkanlıkları ve benzer ritüeller yaratan markalar tüketicilerle özel ve samimi bir bağ oluşturmaktadır. Her geçen yıl artan rekabet koşulları sonucunda markalar tüketicilerinin günlük ritüelleri içinde yer bulmak için pazarlama stratejileri içine ritüelleri almışlar ve sonuç olarak ritüel temelli pek çok tüketim eylemi yaratmışlardır. Güzellik eyleminden kahve içme eylemine kadar oluşturulan ritüeller reklamlar aracılığıyla aktarılmaktadır. Otnes ve Scott'a (1996) göre ritüel ve reklam arasındaki ilişki karşılıklı olarak gelişmekte ve düzenli olarak tekrar edilerek tüketicilere öğretilmektedir. Bu bağlamda reklamlar, markaların kendilerine özgü tüketim ritüellerini sunmalarında ve kendilerini bu tüketim ritüelleri aracılığıyla konumlandırmalarında önemli rol oynamaktadırlar.

$\mathrm{Bu}$ çalışma, reklamlarda yer alan marka ritüellerinin tüketicilerin yaşam tarzlarına ve marka sadakati oluşumuna yansımasını değerlendirmek amacıyla hazırlanmıştır. Araştırmada 4 araştırma sorusuna cevap aranmıştır. "Araştırma Sorusu 1: Tüketiciler ritüelleri yaşamlarının bir parçası olarak görmekte midir?" sorusundan elde edilen bulgularla, literatür kapsamında yer alan ritüel pazarlamasının tüketicilerin zinninde markaya ait bir işaret ve miras değeri yaratma gücü arasında benzerlik saptanmıştır. Ayrıca ritüellerin toplum tarafından tanımlandıkları ve ritüellerin alışkanlıklar ile karşılaştırıldıklarında daha sembolik anlamlar taşıması (Odabaşı, 2013:75) katılımcılar tarafından da belirtilerek geçmişe özlem, kendini özel hissetme gibi ifadelerle açıklanmıştır. Bu çalışmada elde edilen bulgulara göre ritüel yaratan markalar özellikle tüketiciyle bağ kurma sürecinde tüketicinin dikkatini çekmektedir. Ayrıca marka ritüelleri ile geçmiş arasında kurulan ilişki tüketicilerin markaya yönelik olumlu duygular hissetmesini sağlamaktadır.

"Araştırma Sorusu 2: Marka ritüelleri ile kültür arasında bir ilişki var mıdır?" sorusu bağlamında elde edilen bulgulara göre marka ritüellerinin kültüre yansıdığı ve marka ritüellerinin kültürü etkilediği saptanmıştır. Bu bulgu McCracken'a göre (1986) tüketicilere sunulan ürünlerin taşıdıkları kültürel anlamlara ve ritüellere kaynaklık eden kültürün aktarımında reklamların önemli bir araç olduğu bilgisiyle örtüşmektedir. Araştırma kapsamında bireylerin kendilerine yakın gelen markaların ritüellerini kolaylıkla benimsedikleri ve kültüre yansıtılmasını da olumlu değerlendirdikleri ortaya 
çıkmıştır. Ayrıca katılımcılar markalara ait ritüellerin belli bir düzeyde kültürü yansıttığını düşünmektedir. Bunun nedeni olarak reklamların etkisi ve ritüellerin alışkanlıklara sebep olması sonucunda günlük yaşam ve kültür dinamikleri içinde özümsenmesi olduğu belirtilebilmektedir. Ancak küresel markaların yerel unsurları dikkate alması ve ritüel unsurlarını bu çerçevede uygulaması önemlidir. Tüketicilerin özellikle kendi kültürlerine ve yaşam tarzlarına yakın buldukları marka ritüellerini tüketim ritüellerine dönüştürdükleri görülmektedir.

"Araştırma Sorusu 3: Ritüeller marka tercihinde ve tüketim şeklinde etkili midir?" araştırma sorusu bulgularına göre reklam ve tüketim ritüeli arasında bir tüketim ilişkisi olduğu ve reklamların dikkat çektiği saptanmıştır. Reklam mesajlarındaki ritüellerin özellikle dikkat çektiği bulgular arasında yer almaktadır. Bir diğer bulguya göre ritüel yaratan markaların reklamları dikkat çekmektedir. Katılımcıların büyük bir çoğunluğu reklamlarda gördükleri marka ritüellerine ait mesajlara olumlu yaklaştıklarını ve ritüelleri tüketimlerine de yansıttıklarını belirtmiştir. Bu bağlamda markaların özellikle ses, koku, tat gibi duyulara hitap eden ritüelleri sahiplenmesinin tercih sebebi olduğu saptanmıştır. Ancak bu çerçevede hedef kitleye uygun mesaj iletimi ve ritüel unsurlarının önemli olduğu saptanmıştır.

Araştırma kapsamında yer alan "Araştırma Sorusu 4: Ritüeller marka sadakati yaratma sürecinde etkili midir?" sorusu kapsamında markanın bilinçaltına seslenmesi ve markayla bağ kurma sürecinde etkili olması gibi sebeplerle ritüellere olumlu bir bakış açısı olduğu belirlenmiştir. Tüketicilerin zihninde ritüeller bir yaşam tarzına dönüşmekte ve doğal bir süreç olarak markayla özdeşleşen bir hareket haline gelmektedir. Araştırma kapsamında ortaya çıkan bir diğer önemli bulgu ise marka ritüellerinin marka sadakati yaratmada etkili olmasına karşın sadakatin devam etmesinde etkili olmadığı görüşüdür. Bu bağlamda ritüeller, marka sadakatinde destekleyici bir uygulama olarak değerlendirilebilmektedir. Bunun yanı sıra, tüketim ritüellerini yansıtan reklamların dikkat çektiği ancak her zaman tüketiciyi o ritüelleri uygulamaya yönlendirmediği belirtilebilmektedir. Ancak marka sadakati yaratım sürecinde ritüel yaratımının destekleyici bir unsur olduğu söylenebilmektedir. Bir diğer yandan katılımcılardan elde edilen bulgular ışığında markalar, ritüelleri yaratırken bazı tehlikelerle karşı karşıya kalmaktadır. Bu tehlikelerin başında yaratılan ritüellerin tüketici zihninde rakip ürünler için de uygulanabilmesidir. Bu bağlamda markaların ritüel yaratımında tüketiciye kendini özel hissettirmesi ve marka ile tüketici arasında güçlü bir bağ kurması önerilmektedir. Bununla birlikte tüm katılımcıların reklamlarda aktarılan ritüel unsurlarını ürün kullanımlarına yansıtmadıkları saptanmıştır. Özellikle genç yaş grubundaki katılımcıların her ne kadar reklamda yer alan ritüeller dikkatlerini çekse de bunu tüketim ritüellerine yansıtmayı tercih etmedikleri belirlenmiştir.

Genel olarak değerlendirildiğinde ritüellerin yer aldığı reklamlar tüketicilerin dikkatini çekmekte ve tüketiciler yaşam tarzlarına bu ritüelleri yansıtmaktadır. Bu bağlamda ritüelleri kullanan markalar tüketiciyle bağ kurmaktadır.

Ritüel içerikli reklamların günümüzde araştırma gündemine yeni girmiş bir konu olması nedeniyle bu çalışmanın literatüre katkıda bulunacağı düşünülmektedir. Bu konuyla ilgili olarak ileride yapılacak çalışmalarda marka yöneticilerinin neden marka iletişim çalışmalarında ritüele yer verdikleriyle ilgili bir araştırma yapılması önerilmektedir. Ayrıca tüketicilere yönelik anket çalışması yapılarak konuyla ilgili nicel veriler yoluyla 
farklı bulgulara ulaşılması önerilmektedir. Diğer yandan reklam uzmanlarının reklam mesajlarında ritüel içerikli mesajları iletirken nelere dikkat ettiğinin araştırılması da çalışmalara yeni bir bakış açısı sağlayacaktır.

\section{Kaynakça}

Aaker, D.A. (1996). Building Strong Brands. New York: Free Press.

Algesheımer, R., Dholakia, U. M., Herrmann, A. (2005). The Social İfluence Of Brand Community: Evidence From European Car Clubs. Journal Of Marketing, 69, 19-34.

Arık, M. B. (2004). Bir Kültür Endüstrisi Ürünü Olarak 14 Şubat Sevgililer Günü, İstanbul Üniversitesi İletişim Fakültesi Dergisi, 20, 79-87.

Baudrıllard, J. (2015). Tüketim Toplumu Söylenceleri/Yapıları. İstanbul: Ayrıntı Yayınları.

Batı, U. (2015). Tüketici Davranışları Tüketim Kültürü, Psikolojisi Ve Sosyolojisi Üzerine Şeytanın Notları, İstanbul: Alfa Basım.

Belk, R. (1987). A Child's Christmas in America, Journal Of American Culture, 10(1), 87-100.

Belk, R. (1990). Halloween: An Evolving American Consumption Ritual, Advances in Consumer Research, 17, 508-517.

Bocock, R. (2014). Tüketim.(i. Kutluk, Trans.). Ankara: Dost Kitabevi Yayınları.

Chaudrı, A., Holbrook, M. B. (2001). The Chain Of Effects From Brand Trust And Brand Affect To Brand Performance: The Role Of Brand Loyalty, The Journal Of Marketing, 65(2), 81-99.

Coşgun, M. (2012). Popüler Kültür Ve Tüketim Toplumu, Batmanüniversitesi Journal Of Life Sciences, 1 (1), 837-850.

Cowell F. (N.D). Cult Brands. (Elevator E-Book). Retrieved From Http://Enrichment.Elevatoragency. Com/Hubfs/Campaigns/2015-4-Cult-Brands/Cult-Brands-Ebook.Pdf?Utm_Referrer=Http\%3a

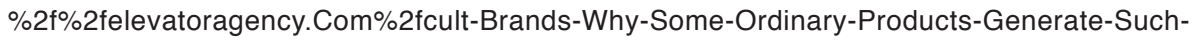
Devoted-Followings\%2f (Erişim Tarihi: 02.04.2016)

Çokluk, Ö. (2011). Nitel Bir Görüşme Yöntemi: Odak Grup Görüşmesi, Kuramsal Eğitimbilim, 4 (1), 95-107.

Dağtaş, E., Dağtaş, B. (2006). Tüketim Kültürü, Yaşam Tarzları, Boş Zamanlar Vemedya Üzerine Bir Literatür Taraması, Eğitim Bilim Toplum, 4(14), S.4-31.

Dıck, A. S., Basu, K. (1994). Customer Loyalty: Toward An Integrated Conceptual Framework,Journal Of The Academy Of Marketing Science, 22(2), 99-113.

Erdoğan, İ. (2006). Teori Ve Pratikte Halkla İlişkiler. Ankara: Erk Yayınları.

Featherstone, M. (2013). Postmodernizm Ve Tüketim Kültürü.(Çeviren: M. Küçük,). İstanbul: Ayrıntı Yayınları. 
Fern, F. E. (2001) Advanced Focus Group Research, Sage Publications, Usa.

Fournıer, S. (1997). Reviving Brand Loyalty: A Reconceptualization Within The Framework Of Consumer-Brand Relationships, International Journal Of Research In Marketing, 14, 451-472.

Gaıner, B. (1995). Ritual And Relationships: Interpersonal Influences On Shared Consumption, Journal Of Business Research, 32(3), 253-261.

Gılde, C., Pace, S., Pervan, S. J., Strong, C. (2011). Examining The Boundary Conditions Of Customer Citizenship Behavior: A Focus On Consumption Ritual, Journal Of Strategic Marketing, 19(7), 619-631.

Holt, D. B. (1992). Examining The Descriptive Value Of "Ritual" In Consumer Behavior: A View From The Field, Advances In Consumer Research, 19, 213-218.

Kazançoğlu, İ., Aytekin, P. (2014). Sevgililer Günü Ritüellerinin Alışveriş Deneyimi Ve Hazcı Alışverişdeğerine Etkisi: Alışveriş Merkezlerinde Bir Uygulama, Uluslararası Yönetim İktisat Ve İşletme Dergisi, 10 (22), 67-93.

Korkmaz, D. F. (2008). Türkiye'de Ramazan Ayı Bağlamında Reklam Kültür Illişkisi.Gazi Üniversitesi Sosyal Bilimler Enstitüsü Yüksek Lisans Tezi., Yayınlanmamış Yüksek Lisans Tezi.

Keller. L. (2001). Building Customer-Based Brand Equity: A Blueprint For Creating Strong Brands. Marketing Sciences Institute, 1(107):1-31.

Levınson, S., Mack, S., Reınhardt, D., Suarez, H., Yeh, C. (1992). Halloween As A Consumption Experience, Advances İn Consumer Research, 19, 219-228.

Lıtosselıtı, L. (2007). Using Focus Groups İn Research, Continuum,3. Baskı, London.

Mccracken, G. (1986). Culture And Consumption: A Theoretical Account Of The Structure And Movement Of The Cultural Meaning Of Consumer Goods, Journal Of Consumer Research, 13, 71-84.

Mckechnıe, S., Tynan, C. (2006). Social Meaning İn Christmas Consumption: An Exploratory Study Of Uk Celebrants' Consumption Rituals, Journal Of Consumer Behavior, 5, Issue 2, 130144.

Mcalexander, J. H., Kım, S. K., Roberts, S. D. (2003). Loyalty: The Influences Of Satisfaction And Brand Community Integration, European Journal Of Marketing Theory And Practice, 11(4), 1-11

Morris, E. (1996). The Brand's The Thing. Fortune,Http://Archive.Fortune.Com/Magazines/ Fortune/Fortune_Archive/1996/03/04/210041/index.Htm

Nambısan, S. Ve Baron, R. A. (2007). Interactions In Virtual Customer Environments: Implications For Product Support And Customer Relationship Management. Journal Of Interactive Marketing, 21 (2), 42-62.

Odabaşı, Y. (2013). Tüketim Kültürü Yetinen Toplumdan Tüketen Topluma. İstanbul: Sistem Yayıncılık. 
Olıver, R. L. (1999). Whence Consumer Loyalty?, Journal Of Marketing, 63 (Özel Sayı), 33-44.

Otnes, C., Scott, L. M. (1996).Something Old, Something New: Exploring The Interaction Between Ritual And Advertising, The Journal Of Advertising, 25 (1), 33-50.

Otnes C. C., Lowreyt. M. (2011). Contemporary Consumption Rituals: A Research Anthology, London: Taylor\&Francis E-Librarys, S. Xvi.

Ödül, D. (2008). Uluslararası Kültürel Farklılıkların Reklamlar Üzerine Yansıması Ve Bir Uygulama. (Yayınlanmamış Yüksek Lisans Tezi). Marmara Üniversitesi Sosyal Bilimler Enstitüsü Yüksek Lisans Tezi.

Rook, D. W. (1985). The Ritual Dimension Of Consumer Behavior, The Journal Of Consumer Research, 12, 251-264.

Rook, D. W. (2001). Ritual Behavior And Consumer Symbolism, Advances In Consumer Research, 279-284.

Sandıkçı, Ö., Ömerakı, S. (2007). Globalization And Rituals: Does Ramadan Turn İnto Christmas?, Advances in Consumer Research, 34, 610-615.

Sherry, J. F. (1987). Advertising As A Cultural System, In J. Umiker-Sebeok(Ed.), Marketing And Semiotics: New Directions In The Study Of Signs For Sale(441-461). New York: Mouton De Gruyter.

Solomon, M. R., (2007). Consumer Behavior: Buying, Having, And Being, New Jersey:Pearson Prentice Hall. (7. Baskı).

Stanfıeld Tetreault, M. A., Kleine, R. E. (1990). Ritual, Ritualized Behavior And Habit: Refinements And Extensions Of The Consumption Ritual Construcy, Advances In Consumer Research, 17, 31 38.

Steward, D. W., Shamdasani, P. N. (2015). Focus Groups Theory And Practice.Usa: Sage Publication. (3. Baskı).

Şentürk, Ü. (2012). Tüketim Toplumu Bağlamında Boş Zamanların Kurumsallaştırdığı Bir Mekan: Alışveriş Merkezleri (Avm), Pamukkale Üniversitesi Sosyal Bilimler Ensitüsü Dergisi, 13, 63-77.

Treıse, D., Wolburg, J. M., Otnes, C. C. (1999). Understanding The "Social Gifts" Of Drinking Rituals: An Alternative Framework For Psa Developers, Journal Of Advertising, 28(2), 17-31.

Tucker, W. T. (1964). The Development Of Brand Loyalty, Journal Of Marketing Research, 1(3), 32-35

Üstüner, T., Ger, G., Holt, D. B. (2000). Consuming Ritual: Reframing The Turkish Henna-Night Ceremony, Advances in Consumer Research, 27, 209-214.

Ün, S. (1996). Reklam-Kültür İlişkisi Ve 1980 Sonrası Türk Reklamcılığının Kültür Değişmelerine Etkisi.İstanbul Üniversitesi Sosyal Bilimler Enstitüsü Yüksek Lisans Tezi. 
Wallendorf, M., Arnould, E. J. (1991). "We Gather Together": Consumption Rituals Of Thanksgiving Day, Journal Of Consumer Research, 18, 13-31.

Wertıme, K. (2002).Building Brands\&Believers: How To Connect With Consumer Using Archetypes, Usa:Wiley.

Yağlıcı, M. (2009). Tüketim Kültürü Ve Ramazan Ayı Televizyon Reklamları. (Yayınlanmamış Yüksek Lisans Tezi). Erciyes Üniversitesi Sosyal Bilimler Enstitüsü Yüksek Lisans Tezi.

Yıngfeng, F. (2011) Study On Effect Of Ritual In Marketing. Proceedings Of The 8th International Conference On Innovation \& Management, 1337-1340. 